\title{
Can outcome of pancreatic pseudocysts be predicted? Proposal for a new scoring system
}

\author{
Kazım Şenol, M.D.,' Özgür Akgül, M.D., ${ }^{1}$ Salih Burak Gündoğdu, M.D.,, ${ }^{1}$ Ihsan Aydoğan, M.D., ${ }^{1}$ \\ Mesut Tez, M.D., ${ }^{1}$ Faruk Çoşkun, M.D., ${ }^{1}$ Deniz Necdet Tihan, M.D. ${ }^{2}$
}

${ }^{1}$ Department of General Surgery, Ankara Numune Training and Research Hospital, Ankara-Turkey

${ }^{2}$ Department of General Surgery, Şevket Yılmaz Training and Research Hospital, Bursa-Turkey

\begin{abstract}
BACKGROUND: The spontaneous resolution rate of pancreatic pseudocysts (PPs) is $86 \%$, and the serious complication rate is $3-9 \%$. The aim of the present study was to develop a scoring system that would predict spontaneous resolution of PPs.

METHODS: Medical records of 70 patients were retrospectively reviewed. Two patients were excluded. Demographic data and laboratory measurements were obtained from patient records.

RESULTS: Mean age of the 68 patients included was 56.6 years. Female:male ratio was I.34:I. Causes of pancreatitis were stones (48.5\%), alcohol consumption (26.5\%), and unknown etiology (25\%). Mean size of PP was $71 \mathrm{~mm}$. Pseudocysts disappeared in 32 patients (47.1\%). With univariate analysis, serum direct bilirubin level $(>0.95 \mathrm{mg} / \mathrm{dL})$, cyst carcinoembryonic antigen (CEA) level $(>1.5)$, and cyst diameter $(>55 \mathrm{~mm}$ ) were found to be significantly different between patients with and without spontaneous resolution. In multivariate analysis, these variables were statistically significant. Scores were calculated with points assigned to each variable. Final scores predicted spontaneous resolution in approximately $80 \%$ of patients.
\end{abstract}

CONCLUSION: The scoring system developed to predict resolution of PPs is simple and useful, but requires validation.

Keywords: Pancreas; prognosis; pseudocyst; scoring system; spontaneous resolution.

\section{INTRODUCTION}

In the revised Atlanta classification, local complications of acute pancreatitis are defined as acute peripancreatic fluid collections, pancreatic pseudocysts, acute pancreatic or peripancreatic necrotic collections, and walled-off necrosis. [1] Pancreatic pseudocysts and peripancreatic fluid collections are the most commonly reported clinical manifestations. ${ }^{[2]}$ Pancreatic pseudocysts (PPs) are defined as fluid collections with no or minimal solid components, surrounded by a nonepithelial wall of fibrous or granulated tissue, arising as a consequence of acute pancreatitis. ${ }^{[I]}$ Incidence ranges from $5 \%$ to $16 \%$ and is reported to be higher in patients with underlying

Address for correspondence: Deniz Necdet Tihan, M.D.

Şevket Yılmaz Eğitim ve Araştırma Hastanesi, Genel Cerrahi Kliniği, Bursa, Turkey

Tel: +90 224 - 2955000 E-mail: dtihan@yahoo.com

Qucik Response Code Ulus Travma Acil Cerrahi Derg

2016;22(2): I50-154

doi: $10.5505 /$ tjtes.2016.07377

Copyright 2016

TJTES chronic pancreatitis. ${ }^{[3]}$ Management of PPs has traditionally included a period of observation from 4 to 6 weeks, allowing the cystic wall to mature. Therapeutic modalities include endoscopic and radiologic intervention, as well as surgical approach. Selection of modality depends upon the etiology, location, size, and clinical course of the pseudocyst. ${ }^{[4]}$ Recent studies have suggested that spontaneous resolution can be safely and effectively achieved in up to $86 \%$ of patients if longer periods of observation are employed. Serious complications may develop in only $3-9 \%$ of cases during an averaged I-year expectant follow-up. ${ }^{[4,5]}$

In the present study, a scoring system designed to predict spontaneous resolution of PPs was developed.

\section{MATERIALS AND METHODS}

The present was an observational cohort study. Medical records of 40 patients with PPs were retrospectively reviewed at the Emergency Surgery Department of the Ankara Numune Training and Research Hospital between January 2005 and June 2012. Patients were identified from hospital records, aided by a computerized search (International Classification of Diseases-10 code K86.3). Definition of pseudocyst was 
taken from the Atlanta classification. Patients who received primary treatment at another hospital and those misclassified were excluded.

Sixty-eight of the initial 70 patients fulfilled the criteria for true PPs, with the exception of postnecrotic collections that constituted walled-off necrosis formation.

Etiology was considered to be of biliary origin when gallstones were found on radiologic examination. Alcohol was registered as the etiological factor when there was history of alcohol abuse. In the absence of gallstones or alcohol abuse, the etiology was considered to be other, or unknown.

Treatments offered were conservative management, percutaneous puncture and/or drainage, and surgery (e.g. internal drainage with cystogastrostomy or cystojejunostomy and resection). Percutaneous puncture and drainage procedures were performed with guidance of ultrasound or computed tomography.

\section{Independent Variables}

Demographic data and the following laboratory measurements were obtained from each patient record: serum amylase, white blood cell count, platelets, hematocrit, calcium, blood glucose, creatinine, blood urea nitrogen, total/direct bilirubin, alkaline phosphatase (AP), lactate dehydrogenase, $\gamma$-glutamyl transferase, alanine aminotransferase, aspartate aminotransferase, cyst diameter, and cyst fluid carcinoembryonic antigen (CEA) level.

\section{Dependent Variable}

Primary endpoint was spontaneous resolution of PPs, including partial and complete resolution, with uneventful followup.

\section{Statistical Analysis}

Continuous data were presented as mean \pm SD, and differences between groups were analyzed with Mann-Whitney $U$ test. Shapiro-Wilk test was used to assess normality. Categorical variables were analyzed with $\chi^{2}$ tests. Logistic regression was used to identify variables associated with spontaneous resolution. To calculate scores, a logistic regression model was developed, in which presence of spontaneous resolution was the dependent variable, and clinical and pathologic variables were considered to be numerical or categorical covariates.

The final model generated a set of independent prognostic variables with $\beta$ regression coefficients, standard error (SE) of coefficients, and $p$ values. The fit of the model was verified by the Hosmer-Lemeshow goodness-of-fit test. Clinical scores were based on the final logistic regression model. Model discrimination was determined by measuring by the area under the receiver operating characteristic (ROC) curve (AUC). Discrimination of a prognostic model is considered to be perfect if $A \cup C=1$, good if $A \cup C>0.8$, moderate if $A \cup C$ is $0.6-0.8$, and poor if $A \cup C<0.6$.

\section{RESULTS}

Mean (SD) age of patient population was 56.6 (16.7) years, and female:male ratio was I.34:I. Causes of pancreatitis were stones (48.5\%), alcohol (26.5\%), and unknown (25\%). The most common symptom associated with the complicated clinical course of the disease was abdominal pain (in 42 patients, $61.7 \%)$.

Mean size of pseudocyst was $7 \mathrm{II} \pm 54 \mathrm{~mm}$ (range: 8-240 mm). PPs were located around the head of the pancreas in 42 patients (61.8\%), and in the body or tail of the pancreas in 26 patients (28.2\%). Demographic characteristics are shown in Table I.

Table I. Demographic and clinical characteristics of patients with and without spontaneous resolution

\begin{tabular}{|c|c|c|c|}
\hline Variable & Spontaneous resolution $(n=32)$ & Required intervention $(n=36)$ & $\mathbf{p}$ \\
\hline Mean age & $53 \pm 14$ & $55 \pm 15$ & NS \\
\hline Sex, male/female & $13 / 19$ & $16 / 20$ & NS \\
\hline Pancreatitis history (present/absent) & $24 / 8$ & $26 / 10$ & NS \\
\hline White blood cell count (per $\mathrm{mm}^{3}$ ) & $9.357 \pm 5.2$ & $10.533 \pm 4.9$ & NS \\
\hline Cyst fluid CEA level $(0-2.5 \mathrm{ng} / \mathrm{mL})$ & $1.59 \pm 1.53$ & $2.36 \pm 1.46$ & 0.002 \\
\hline Serum glucose level (mg/dL) & $174 \pm 1 \mid 4$ & $147 \pm 73$ & NS \\
\hline Serum amylase level (U/L) & $397 \pm 81.5$ & $454 \pm 97.7$ & NS \\
\hline Serum alkaline phosphatase level (U/L) & $113.9(31)$ & $110.1(32)$ & NS \\
\hline Serum lactate dehydrogenase level (U/L) & $259 \pm 130$ & $250 \pm 118$ & NS \\
\hline Serum direct bilirubin level (mg/dl) & $1.07 \pm 0.97$ & $2.32 \pm 1$ & 0.004 \\
\hline Cyst diameter (mm) & $35 \pm 9$ & $7 I \pm 8$ & 0.004 \\
\hline
\end{tabular}

CEA: Carcinoembryonic antigen. 
Table 2. Multivariable logistic regression model for prediction of spontaneous resolution

\begin{tabular}{lcccc}
\hline & Regression coefficient & Standard error of coefficient & p & Score points \\
\hline Elevated direct bilirubin level $(>0.9 \mathrm{mg} / \mathrm{dL})$ & 1.8 & 1.3 & 0.03 & 1 \\
Elevated CEA $(>1.5)$ & 2.9 & 1.2 & 0.008 & 2 \\
Cyst diameter $(>55 \mathrm{~mm})$ & 1.2 & 0.9 & 0.04 & 1 \\
\hline
\end{tabular}

CEA: Carcinoembryonic antigen.

Table 3. Scoring system for spontaneous resolution and resolution rates

\begin{tabular}{|c|c|c|c|c|c|}
\hline \multicolumn{2}{|c|}{ Pancreatic pseudocysts score } & \multicolumn{2}{|c|}{ Number of patients } & \multicolumn{2}{|c|}{ Spontaneous resolution } \\
\hline Score & Points & $\mathbf{n}$ & $\%$ & $\mathbf{n}$ & $\%$ \\
\hline 1 & 0 & 12 & 17.9 & II & 91.7 \\
\hline II & 1 & 23 & 34.3 & 13 & 56.5 \\
\hline III & 2 & 14 & 20.9 & 5 & 35.7 \\
\hline IV & $>2$ & 19 & 27.9 & 3 & 16.7 \\
\hline
\end{tabular}

Pseudocyst disappeared in 32 (47.1\%) patients, $24(66.6 \%)$ patients underwent external drainage, 7 (19.4\%) underwent cystogastrostomy, 3 (8.3\%) underwent cystojejunostomy, and $2(5.5 \%)$ underwent pancreas resection. With univariate analysis, serum direct bilirubin levels $(>0.95 \mathrm{mg} / \mathrm{dL})$, cyst CEA levels $(>I .5)$, and cyst diameters $(>55 \mathrm{~mm}$ ) were found to be significantly different between patients with and without spontaneous resolution. With multivariate analysis, the same variables were found to be statistically significant (Table 2). Scores were calculated by assigning points to these variables. In spite of differences in regression coefficients, which ranged from I.2 to 2.9 , for the sake of simplicity, I point was assigned for cyst diameter (>55 mm), 2 points were assigned for cyst CEA level (>I.5), and I point was assigned for serum direct bilirubin level $(>0.95 \mathrm{mg} / \mathrm{dL})$. The resulting score ranged from 0 to 4 .

Four groups of patients were identified, based on score. The first group (score I) had a spontaneous resolution rate of $91.7 \%$, comprised approximately $17.9 \%$ of the cohort, and included patients with 0 points. The second group (score 2) had a spontaneous resolution rate of $56.5 \%$, comprised approximately $34.3 \%$ of the cohort, and included patients with I point. The third group (score 3 ) had a spontaneous resolution rate of $35.7 \%$, comprised approximately $20.9 \%$ of the cohort, and included patients with 2 points. Spontaneous resolution rates were $16.7 \%$ and $0 \%$ for patients with 3 and 4 points, respectively (score 4). Rates are displayed in Table 3.

The Hosmer-Lemeshow goodness-of-fit test of the final model was $p=0.96 \mathrm{I}$, indicating a quite adequate fit of the model to the data. AUC of the new score was 0.789 (0.682 to 0.896$)$.

\section{DISCUSSION}

Primary treatment modality of PPs involves conservative approaches until the PPs become asymptomatic. ${ }^{[6]}$ Recent studies have concluded that $8-86 \%$ of PPs resolve spontaneously, while $5-15 \%$ of collections form symptomatic mature pseudocysts. ${ }^{[7]}$ During an averaged I-year expectant follow-up, 3-9\% of mature PPs presented with serious complications, including infection, bleeding, and jaundice. ${ }^{[4]}$ PPs larger than 6 $\mathrm{cm}$ are closely correlated with increased risk of complication. [5] It has been demonstrated in a majority of related studies that PPs larger than 5 or $6 \mathrm{~cm}$ have lower rates of spontaneous resolution. ${ }^{[8-11]}$ Authors have emphasized that, depending on size, early operation or drainage of pseudocyts improves rates of morbidity and mortality. ${ }^{[12]}$ Therefore, it is strongly suggested that surgical or percutaneous drainage be considered in cases of PPs larger than $6 \mathrm{~cm} .{ }^{[6]}$ While data regarding PP size and clinical course varies between studies, cysts smaller than $4 \mathrm{~cm}$ are considered to be independent factors for spontaneous resolution and favorable outcome. ${ }^{[4,13]}$

In the present study, $47 \%$ of PPs showed uneventful partial or complete resolution during early stages of follow-up (mean: $15 \pm$ II.55 months). Significant differences in cyst diameter were found between the resolution and intervention groups ( $35 \pm 9 \mathrm{~mm}$ vs $7 \mathrm{I} \pm 8 \mathrm{~mm}, \mathrm{p}=0.004)$. More complicated clinical courses were observed in the intervention group, related to increased PP size. Both univariate and multivariate analysis demonstrated that cyst diameter $<53 \mathrm{~mm}$ was a predictive factor for spontaneous resolution. Differences in cyst diameter among groups indicated that percutaneous intervention and/or surgical treatment must be considered as treatment options for larger PPs, in accordance with the literature. 
However, Cheruvu et al. have demonstrated that size of pseudocyst is a less-important indicator. Clinical outcomes of patients with median PP size of $8 \mathrm{~cm}$ and median PP size of $7 \mathrm{~cm}$ required intervention, and patients in both groups received conservative treatment. ${ }^{[14]}$ In addition, Nguyen et al. demonstrated similar results regarding rates of spontaneous resolution, intervention, recurrence, and mortality in PPs larger or smaller than $6 \mathrm{~cm}$. The authors concluded that etiology of AP is a more efficient means of predicting clinical outcome than cyst size. ${ }^{[15]}$ Thus, pseudocyst size is not a significant indicator of spontaneous resolution, requiring more efficient parameters for the prediction of eventual outcome.

PPs comprise $75 \%$ of pancreatic cysts. History of unnoticed acute pancreatitis renders distinction between cystic neoplasms, retention cysts, congenital cysts, and pseudocysts difficult until intervention is performed. ${ }^{[16]}$ In a clinical setting, data obtained from cyst fluid informs the differential diagnosis of a pseudocyst. No remarkable literature regarding biological predictive factors for spontaneous resolution of PPs could be found. Complicated clinical course of PPs and practical manifestation of serum markers should lead clinicians to consider the option of medical therapy. Several studies have shown that cyst fluid analysis with elevated amylase in the thousands and low CEA level $(<192 \mathrm{ng} / \mathrm{mL})$ supports the diagnosis of a pseudocyst and helps determine the optimal therapeutic strategy by excluding pancreatic cystic malignancies. ${ }^{[17-19]}$ Cyst fluid may contain acute and chronic inflammatory cells, histiocytes, and macrophages. ${ }^{[20]}$ Only complicated cases with gastrointestinal epithelial and mucin contamination, particularly from the stomach, should include cystic lining epithelial cells. [19,21,22] Van der Waaij et al. analyzed 12 studies and demonstrated that CEA levels below $5 \mathrm{ng} / \mathrm{mL}$ present a specificity of $95 \%$ for pseudocyst formation. ${ }^{[18]}$ Biliary complications of PPs manifest as obstructive jaundice, requiring intervention until the pseudocyst resolves. Jaundice may result from distortion and narrowing of the intra-pancreatic segment of the common bile duct by progressive fibrosis of the pancreatic tissue, as exhibited in cases of chronic pancreatitis (or rarely by compression of the duct by a pseudocyst). ${ }^{[23,24]}$

In the present study, cyst fluid CEA mean levels were significantly lower in the resolution group than in the intervention group ( $1.59 \pm 1.53 \mathrm{ng} / \mathrm{mL}$ vs $2.36 \pm 1.46 \mathrm{ng} / \mathrm{mL}, \mathrm{p}=0.002)$. This indicated a correlation between higher levels of CEA and complicated clinical course of disease. When CEA levels did not indicate malignancy, pseudocyst fluid levels with CEA>I.5 ng/ $\mathrm{mL}$ demonstrated inverse predictive power of spontaneous resolution. In addition, 21 patients (32.3\%) had symptoms of jaundice, while only 4 (5.8\%) responded well to conservative treatment. Serum direct bilirubin levels of the resolution group were significantly lower than those of the intervention group $(1.07 \pm 0.97 \mathrm{mg} / \mathrm{dL}$ vs $2.32 \pm \mathrm{I} \mathrm{mg} / \mathrm{dL}, \mathrm{p}=0.004)$. In both univariate and multivariate analyses, elevation of direct bilirubin levels higher than $0.95 \mathrm{mg} / \mathrm{dL}$ were closely correlated with surgical or percutaneous intervention and lower rates of resolution.
In routine practice, asymptomatic PPs are safely observed, depending on size and location of cyst and secondary complications. Treatment algorithms and indications for therapeutic intervention were primarily developed according to challenges faced in the management of the disease. Therefore, accurate and effective prognostic scoring systems are essential to prevent characteristic complications of PPs and attendant therapeutic challenges.

\section{Conclusion}

A scoring system based on cyst diameter, serum direct bilirubin, and cyst CEA level was developed in the present study. This system is simple and employs routinely collected radiologic and laboratory parameters. PPs with cyst diameter $<53$ $\mathrm{mm}$, cyst fluid CEA level $<1.5 \mathrm{ng} / \mathrm{mL}$, and serum direct bilirubin level $<0.9 \mathrm{mg} / \mathrm{dL}$ have high tendency to spontaneously resolve. PPs with scores of 3 and 4 are complicated, with unfavorable clinical outcomes. Adverse outcome and prolonged follow-up should be reduced by applying this scoring system during management of the disease in a clinical setting. The present retrospective cohort study requires validation with prospective randomized clinical studies.

Conflict of interest: None declared.

\section{REFERENCES}

1. Banks PA, Bollen TL, Dervenis C, Gooszen HG, Johnson CD, Sarr MG, et al. Classification of acute pancreatitis--2012: revision of the Atlanta classification and definitions by international consensus. Gut 2013;62:102-11. CrossRef

2. Cui ML, Kim KH, Kim HG, Han J, Kim H, Cho KB, et al. Incidence, risk factors and clinical course of pancreatic fluid collections in acute pancreatitis. Dig Dis Sci 2014;59:1055-62. CrossRef

3. Kim KO, Kim TN. Acute pancreatic pseudocyst: incidence, risk factors, and clinical outcomes. Pancreas 2012;41:577-81. CrossRef

4. Samuelson AL, Shah RJ. Endoscopic management of pancreatic pseudocysts. Gastroenterol Clin North Am 2012;41:47-62. CrossRef

5. Bergman S, Melvin WS. Operative and nonoperative management of pancreatic pseudocysts. Surg Clin North Am 2007;87:1447-60. CrossRef

6. Behrns KE, Ben-David K. Surgical therapy of pancreatic pseudocysts. J Gastrointest Surg 2008;12:2231-9. CrossRef

7. Cannon JW, Callery MP, Vollmer CM Jr. Diagnosis and management of pancreatic pseudocysts: what is the evidence? J Am Coll Surg 2009;209:385-93. CrossRef

8. Sankaran $\mathrm{S}$, Walt AJ. The natural and unnatural history of pancreatic pseudocysts. Br J Surg 1975;62:37-44. CrossRef

9. Warshaw AL, Rattner DW. Timing of surgical drainage for pancreatic pseudocyst. Clinical and chemical criteria. Ann Surg 1985;202:720-4.

10. Yeo CJ, Bastidas JA, Lynch-Nyhan A, Fishman EK, Zinner MJ, Cameron JL. The natural history of pancreatic pseudocysts documented by computed tomography. Surg Gynecol Obstet 1990;170:411-7.

11. Walt AJ, Bouwman DL, Weaver DW, Sachs RJ. The impact of technology on the management of pancreatic pseudocyst. Fifth annual Samuel Jason Mixter Lecture. Arch Surg 1990;125:759-63. CrossRef

12. Behrman SW, Melvin WS, Ellison EC. Pancreatic pseudocysts following acute pancreatitis. Am J Surg 1996;172:228-31. CrossRef 
13. Gouyon B, Lévy P, Ruszniewski P, Zins M, Hammel P, Vilgrain V, et al. Predictive factors in the outcome of pseudocysts complicating alcoholic chronic pancreatitis. Gut 1997;41:821-5. CrossRef

14. Cheruvu CV, Clarke MG, Prentice M, Eyre-Brook IA. Conservative treatment as an option in the management of pancreatic pseudocyst. Ann R Coll Surg Engl 2003;85:313-6. CrossRef

15. Nguyen BL, Thompson JS, Edney JA, Bragg LE, Rikkers LF. Influence of the etiology of pancreatitis on the natural history of pancreatic pseudocysts. Am J Surg 1991;162:527-31. CrossRef

16. Pitchumoni CS, Agarwal N. Pancreatic pseudocysts. When and how should drainage be performed? Gastroenterol Clin North Am 1999;28:615-39. CrossRef

17. Brugge WR, Lewandrowski K, Lee-Lewandrowski E, Centeno BA, Szydlo T, Regan S, et al. Diagnosis of pancreatic cystic neoplasms: a report of the cooperative pancreatic cyst study. Gastroenterology 2004;126:1330-6.

18. van der Waaij LA, van Dullemen HM, Porte RJ. Cyst fluid analysis in the differential diagnosis of pancreatic cystic lesions: a pooled analysis. Gastrointest Endosc 2005;62:383-9. CrossRef
19. Gonzalez Obeso E, Murphy E, Brugge W, Deshpande V. Pseudocyst of the pancreas: the role of cytology and special stains for mucin. Cancer 2009;117:101-7. CrossRef

20. Pitman MB, Lewandrowski K, Shen J, Sahani D, Brugge W, Fernandezdel Castillo C. Pancreatic cysts: preoperative diagnosis and clinical management. Cancer Cytopathol 2010;118:1-13. CrossRef

21. Nagle JA, Wilbur DC, Pitman MB. Cytomorphology of gastric and duodenal epithelium and reactivity to B72.3: a baseline for comparison to pancreatic lesions aspirated by EUS-FNAB. Diagn Cytopathol 2005;33:381-6. CrossRef

22. Nawgiri RS, Nagle JA, Wilbur DC, Pitman MB. Cytomorphology and B72.3 labeling of benign and malignant ductal epithelium in pancreatic lesions compared to gastrointestinal epithelium. Diagn Cytopathol 2007;35:300-5. CrossRef

23. Gonzalez LL, Jaffe MS, Wiot JF, Altemeier WA. Pancreatic pseudocyst: A cause of obstructive jaundice. Ann Surg 1965;161:569-76. CrossRef

24. Warshaw AL, Rattner DW. Facts and fallacies of common bile duct obstruction by pancreatic pseudocysts. Ann Surg 1980;192:33-7. CrossRef

\section{ORİJINAL ÇALIŞMA - ÖZET}

\section{Pankreatik psödokistin sonuçları tahmin edilebilir mi? Yeni bir skorlama sistemi önerisi Dr. Kazım Şenol, ${ }^{1}$ Dr. Özgür Akgül, ${ }^{1}$ Dr. Salih Burak Gündoğdu, ${ }^{1}$ Dr. İhsan Aydoğan, ${ }^{1}$ Dr. Mesut Tez, ${ }^{1}$ Dr. Faruk Çoşkun, ${ }^{1}$ Dr. Deniz Necdet Tihan ${ }^{2}$}

${ }^{1}$ Ankara Numune Eğitim ve Araştırma Hastanesi, Genel Cerrahi Kliniği, Ankara Şevket Yılmaz Eğitim ve Araştırma Hastanesi, Genel Cerrahi Kliniği, Bursa

AMAÇ: Pankreatik psödokistlerinde spontan rezolüsyon oranı \%86, ciddi komplikasyon oranı ise \%3-9 olarak bildirilmektedir. Bu çalışmanın amacı psödokistlerin spontan rezolüsyonunu öngörebilen yeni bir skorlama sistemi geliştirmektir.

GEREÇ VE YÖNTEM: Yetmiş hastanın tıbbi kayıtları geçmişe yönelik incelendi. İki hasta çalışma dışı bırakıldı. Her hastanın kayıtlarından demografik verileri ve laboratuvar değerleri elde edildi.

BULGULAR: Altmış sekiz hastanın ortalama yaşı 56.6 ve kadın/erkek oranı I.34/I olarak bulundu. Hastaların \%48.5'inde pankreatitin nedeni safra taşları, \%26.5'inde kronik alkol kullanımı, \%25'inde ise idiopatikti. Ortalama kist çapı 7 I mm idi. Takip esnasında 32 hastada (\%47.I) psödokist kayboldu. Tek değişkenli analizler incelendiğinde kist çapı (>55 mm) ile serum dierkt bilirübin (>0.95 mg/dL) ve kist CEA (>I.5) değerlerinin spontan rezolüsyon saptanan ve saptanmayan hastalar arasında anlamlı derecede farklı olduğu görüldü. Çok değişkenli analizler sonrasında da aynı değişkenlerde istatistiksel anlamlı farklılık saptandı. Skorlar bu değişkenlere atanan puanlar toplanarak elde edildi. Nihai puanlar ile \%80 hastada spontan rezolüsyon tahmin edilebildi.

TARTIŞMA: Basit ve kolay uygulanabilir olan skorlama sistemimiz ile psödokist rezolüsyonunu tahmin etmek mümkün olabileceği kannatindeyiz; yine de geçerlilik ve güvenilirliğinin daha detaylı değerlendirilmesi gerekmektedir.

Anahtar sözcükler: Pankreas; prognoz; psödokist; skorlama sistemi; spontan rezolüsyon.

Ulus Travma Acil Cerrahi Derg 2016;22(2):I50-154 doi: 10.5505/tjtes.2016.07377 